УДК 347.43(477)

DOI https://doi.org/10.32837/pyuv.v0i5(34).648

\author{
В. В.Рассказова \\ orcid.org/0000-0003-0887-4880 \\ старший викладач кафедри цивільного права та процесу \\ Харківського національного університету внутрішніх справ
}

\title{
ПРИПИНЕННЯ ОКРЕМИХ ВИДІВ ЗОБОВ'ЯЗАНЬ ВІДСТУПНИМ
}

Постановка проблеми. Сучасна практика виникнення, розвитку та припинення цивільних правовідносин вимагає від учасників застосування ефективних та водночас оперативних способів управління динамікою зобов'язання, адже важливим для сторін є врахування інтересів та потреб кожної з них на всіх етапах існування зобов'язання, а також вчасне попередження небажаних негативних наслідків невиконання, неналежного виконання умов договору або їх настання у зв'язку з будь-якими іншими обставинами. Одним із найбільш гнучких та універсальних інструментів припинення зобов'язання є конструкція відступного, застосування якої в договірній практиці є відображенням диспозитивності та прямої дії принципу свободи договору. Так, згідно зі ст. 600 Цивільного кодексу України (далі - ЦК) зобов'язання [1] припиняється за згодою сторін унаслідок передання боржником кредиторові відступного (грошей, іншого майна тощо). Розмір, строки й порядок передання відступного встановлюються сторонами.

Стан дослідження. Питанням особливостей юридичної природи, правової регламентації ролі й місця відступного в системі підстав припинення зобов'язання, з'ясуванню проблем у практиці застосування цього інституту присвячено чимало наукових праць як щодо загальних аспектів припинення зобов'язання, так і щодо відступного. Питанням ознак відступного як самостійної підстави припинення цивільного зобов'язання, його відмінностей від інших суміжних інститутів зобов'язального права, особливостей застосування цього механізму ліквідації юридичних зв'язків між сторонами та його наслідків висвітлено в працях А.М. Блащука, Т.В. Боднар, А.В. Коструби [2], О.Я. Кузьмича, О.І. Міхно, Є.В. Падуна [3], І.Й. Пучковської, Ф.А. Шимка [4], О.С. Яворської [5] та інших. Водночас окремої уваги потребують питання припинення відступним окремих видів зобов'язання.

Метою статті є з'ясування можливості та особливостей застосування цієї підстави припинення певного виду зобов'язання 3 урахуванням його сутності та змісту. Доцільність дослідження окреслених питань слід пояснити важливим значенням відповідних теоретичних напрацювань не лише для сучасної доктрини цивільного права, але й для практики застосування цієї правової конструкції щодо різних видів зобов'язань, яка, власне, свідчить про виникнення складних правових питань у застосуванні відступного як підстави припинення певних видів цивільних зобов'язань та відсутність єдиного підходу до їх вирішення. Аналіз зазначеної проблематики дозволить сформувати уявлення про напрями подальшого вдосконалення відповідного законодавчого регулювання та забезпечення єдності практики застосування інституту відступного.

Для досягнення окресленої мети автор ставить перед собою завдання здійснити аналіз та сформулювати загальний висновок щодо особливостей припинення певних видів цивільних зобов'язань відступним, а також надати авторські пропозиції шляхів удосконалення законодавчої регламентації щодо передання відступного як підстави припинення зобов'язання.

Виклад основного матеріалу. Як убачається 3 аналізу положень ст. 600 ЦК, законодавець не обмежує сторін у виборі предмета відступного, закріплюючи невичерпний перелік майнових цінностей як відступного (рухомі, нерухомі речі, майнові комплекси підприємств, майнові права i навіть виконання робіт, надання послуг), як і не обмежує в застосуванні відступного для припинення будь-яких зобов'язань (як договірних, так і деліктних) та на будь-якій стадії розвитку зобов'язальних правовідносин.

Проте в юридичній літературі висловлюються думки щодо необхідності встановлення прямих заборон застосування відступного або особливих умов його передання залежно від виду та сутності певних видів зобов'язань. Так, як зазначає О.С. Яворська, «у договорах постачання енергетичних та інших ресурсами через приєднану мережу, контрактації сільськогосподарської продукції, договорах поставки для задоволення пріоритетних державних потреб, на державне замовлення, з огляду на правову спрямованість, особливий суб'єктний склад, правовий режим об'єктів передання відступного мало б допускатися за певних умов, оскільки таке може вплинути на інтереси третіх осіб, позначитися на поповненні державних матеріальних запасів, фондів, страхових резервів тощо, дестабілізувати відносини в тих чи інших сегментах ринку» [3, с. 206]. 
На нашу думку, цілком слушними є зауваження дослідників щодо необхідності законодавчого визначення випадків або умов, за яких не допускається припинення зобов'язання відступним, адже передання відступного за деякими видами цивільних зобов'язань може суперечити юридичній природі такого зобов'язання.

Варто звернути увагу, що в ЦК міститься пряма заборона застосування новації (ч. 3 ст. 604) та зарахування (п. 1 ч. 1 ст. 602), наприклад, щодо зобов'язань про відшкодування шкоди, завданої каліцтвом, іншим ушкодженням здоров'я або смертю. Зрозуміло, що вказані підстави припинення зобов'язань є відмінними від відступного та в силу своїх особливостей унеможливлюють припинення вказаних зобов'язань у такий спосіб, але, на нашу думку, подібний підхід законодавця щодо обмеження випадків застосування тієї чи іншої підстави припинення зобов'язання має бути збережений i відображений стосовно інституту відступного також.

Взагалі, питання щодо можливості припинення деліктного зобов'язання переданням відступного є досить дискусійним, адже відсутність чіткої регламентації випадків, умов та порядку застосування цього правового інституту щодо зобов'язань з відшкодування шкоди може мати наслідком погіршення становища потерпілої сторони, отримання меншого відшкодування, ніж те, на яке особа має право за законом, а також укладення угоди про передання відступного, яка, хоча і є волевиявлення сторін та втіленням принципу свободи договору, але водночас не виключено, що може суперечити інтересам потерпілого.

На думку О. Отраднової, досягнення згоди щодо передання відступного є цілком законним способом припинення деліктного зобов'язання та відповідає основному його призначенню - задоволенню інтересів потерпілого [6, с. 253]. Єдине питання, що виникає при цьому, на думку дослідниці, полягає в тому, чи може відступне бути меншим за вартістю, ніж повний обсяг завданої шкоди.

Із цього приводу в юридичній літературі висловлюються різні думки, зокрема: передача відступного припиняє основне зобов'язання, а тому через підписання угоди про відступне навіть у меншому обсязі та його отримання потерпілий втрачає право вимоги до заподіювача шкоди, а останній втрачає обов'язок відшкодувати шкоду в повному обсязі. У випадках відшкодування шкоди, завданої каліцтвом, іншим ушкодженням здоров'я або смертю, якщо потерпілий погоджується на отримання відступного в меншому розмірі, пріоритет має воля сторін деліктного зобов'язання [6, с. 253]; у будь-якому разі передання відступного не може погіршувати становище кредитора (потерпілої сторони в деліктному зобов'язанні) [3, с. 210].
Вважаємо, що випадок передання потерпілій стороні відступного в меншому розмірі, ніж повний обсяг завданої шкоди, породжує конфлікт між правом сторін вибрати такий спосіб припинення зобов' язання, засадою свободи договору та загальним імперативом ч. 1 ст. 1166 ЦК України щодо такого принципу деліктного зобов' язання, як відшкодування завданої шкоди в повному обсязі особою, яка її завдала.

Звичайно, варто погодитися, що в цілому передання відступного за угодою між сторонами позадоговірного зобов'язання $€$ досить ефективним способом задоволення інтересів потерпілого в отриманні відповідного відшкодування, проте, на нашу думку, важливим при цьому є забезпечення належного рівня законодавчого регулювання подібних випадків з тим, щоб запобігти зловживанню відступним з метою ухилення від відповідальності за заподіяну шкоду та порушенню права потерпілого на повне відшкодування завданої шкоди. Тож, на наш погляд, застосування інституту відступного з метою припинення деліктного зобов'язання має здійснюватися з деякими застереженнями, зокрема, порядок та умови його застосування мають відповідати вимозі задоволення інтересів потерпілої сторони у відшкодуванні шкоди в повному обсязі, крім винятків із цього загального правила, передбачених законом. Хоча це і є певним обмеженням сторін у вільному визначенні розміру відступного, проте цілком відповідає природі позадоговірного зобов' язання, адже сторони, на відміну від договірних зобов'язань, не за домовленістю вступили в деліктні правовідносини.

Щодо припинення відступним інших видів зобов' язань варто зазначити, що досить поширеним на практиці є припинення в такий спосіб договірних зобов'язань, що виникають на підставі договорів позики, про надання послуг та ін. Проте в таких випадках сторони вільні на власний розсуд припинити існуюче зобов'язання, орієнтуючись на свої інтереси та задоволення потреб як на даний час, так і в майбутньому, оскільки, вступаючи у правовідносини, за домовленістю між собою добровільно взяли на себе зобов'язання, а отже, визначення його подальшої долі також залежить від розсуду сторін і є питанням узгодження розміру, строку і порядку передання боржником i прийняття кредитором предмета відступного. I передання боржником відступного в розмірі меншому, ніж має отримати за договором кредитор, якщо це узгодили сторони, не суперечить чинному законодавству і є цілком законним способом припинення зобов'язання.

При цьому важливими умовами досягнення мети припинення відповідних зобов'язань передачею відступного є виконання всіх вимог ст. 600 ЦК, чим нерідко нехтують сторони та, 
як наслідок, надалі вирішують спірні питання в судовому порядку.

Так, Верховний Суд звертає увагу, що для припинення зобов'язання переданням відступного необхідна сукупність кількох умов, зокрема: згода сторін на таке припинення; узгодження сторонами розміру, строків і порядку передання відступного; факт передання боржником кредиторові відступного. Обов'язковість досягнення згоди щодо припинення зобов'язань відступним тягне за собою необхідність відповідної фіксації такої згоди. Таким чином, відступне має бути оформлене договором, в якому вказуються розмір відступного, порядок та строк його надання (правові висновки містяться в постановах Верховного Суду від 02 грудня 2020 року в справі № 569/22588/18; від 12 квітня 2018 р. у справі № 761/37012/15-ц, від 23 вересня 2020 року в справі № 497/1085/16-ц).

В одній зі справ суд апеляційної інстанції також звернув увагу, що «відступне - це передача боржником кредитору замість виконання первісного зобов' язання певного майна або сплата певної суми грошей, або передача інших прав; відступне, зі згоди кредитора, наділяє боржника можливістю замінити первісний предмет виконання іншим предметом у випадку, якщо він не може виконати первісне зобов'язання; застосування відступного можливе тільки за узгодженням сторін; відступне в обов'язковому порядку передбачає наявність істотних його умов: розміру, термінів і порядку передачі; істотні умови відступного встановлюються сторонами первісного зобов'язання; передача відступного частково або в повному обсязі припиняє первісні зобов'язання сторін. Таким чином, важливою ознакою відступного є мета, якою сторони керуються під час застосування цієї конструкції, і власне функція цього правового інституту - припинення зобов' язальних відносин між сторонами» [7].

Тому очевидно, що застосування інституту відступного, зокрема в грошових зобов'язаннях, $€$ ефективним механізмом припинити небажані правові зв' язки між сторонами основного зобов' язання, досягнувши при цьому вигідних для обох сторін умов на конкретному етапі розвитку правовідносин. Проте важливим є виконання необхідних вимог щодо фіксації всіх істотних умов угоди про передачу відступного.

Висновки і перспективи подальших досліджень. Аналіз окремих аспектів припинення деліктних зобов'язань переданням відступного свідчить про існування різних концептуальних підходів до вирішення цього питання в доктрині цивільного права. Важливим при цьому є забезпечення належного рівня законодавчого регулювання подібних випадків з тим, щоб запобігти зловживанню відступним з метою ухилення від відповідальності за заподіяну шкоду та порушенню права потерпілого на повне відшкодування завданої шкоди.

Вбачається, що застосування інституту відступного 3 метою припинення деліктного зобов' язання має здійснюватися з деякими застереженнями, зокрема, порядок та умови його застосування мають відповідати вимозі задоволення інтересів потерпілої сторони у відшкодуванні шкоди в повному обсязі. Хоча це і $є$ певним обмеженням сторін у вільному визначенні розміру відступного, проте цілком відповідає природі позадоговірного зобов' язання.

Також застосування інституту відступного з метою припинення низки договірних зобов'язань є ефективним і досить поширеним у практиці правозастосування, що дозволяє ліквідувати небажані юридичні зв'язки між сторонами 3 досягненням вигідних для обох сторін умов на конкретному етапі розвитку правовідносин. Важливим при цьому є виконання необхідних вимог щодо фіксації всіх істотних умов угоди про передачу відступного.

Крім того, проведене дослідження зазначених питань відкриває нові напрями для подальших наукових пошуків, демонструє актуальність та необхідність більш детального та комплексного аналізу досліджуваної проблематики, в тому числі вивчення зарубіжного досвіду в питаннях правового регулювання припинення окремих видів зобов'язань відступним.

\section{Jimepamypa}

1. Цивільний кодекс України : Закон України від 16.01.2016 р. № 435-IV. Дата оновлення: 16.10 .2020 p. URL: http://zakon.rada.gov.ua/laws/show/435-15 (дата звернення: 14.12.2020).

2. Коструба А.В. До питання про особливості механізму припинення зобов'язань в силу правоприпиняючого юридичного факту - передання відступного. Альланах права. 2012. Вип. 3. С. 371-374.

3. Падун Є.В. Критерії відмежування відступного від новації в цивільному праві України. Науковий вісник Національної академї внутрішніх справ. 2013. № 3. C. 91-97. URL: http://nbuv.gov.ua/UJRN/ Nvknuvs_2013_3_13 (дата звернення: 16.12.2020).

4. Шимко Ф.А. Прощення боргу як спосіб припинення зобов'язань : автореф. дис. ... канд. юрид. наук : 12.00.03. Харків, 2016.19 с.

5. Яворська О.С. Передання відступного як підстава припинення цивільного зобов'язання. Актуальні проблели вдосконалення чинного законодавства України. 2013. Вип. 31. С. 205-215. URL: http://nbuv.gov.ua/UJRN/apvchzu_2013 3123 (дата звернення: 16.12.2020).

6. Отраднова О. Способы прекращения деликтных обязательств по воле сторон: украинский опыт. Закон и жизнь. Кишинев, 2013. № 08/2 (260). C. 251-255. URL: http://www.legeasiviata.in.ua/ archive/2013/8-2/64.pdf (дата звернення: 16.12.2020).

7. Постанова Київського апеляційного суду від 24.09.2020 року у справі № 366/1844/19. URL: https://reyestr.court.gov.ua/Review/92730961 (дата звернення: 16.12.2020). 


\section{Анотація}

Рассказова В. В. Припинення окремих видів зобов'язань відступним. - Стаття.

У статті на підставі наявних наукових напрацювань і судової практики досліджено особливості та взагалі можливість застосування відступного як одного з найбільш гнучких та універсальних інструментів припинення договірних і позадоговірних зобов'язань, ураховуючи їхню юридичну природу.

За результатами проведеного дослідження встановлено, що серед дослідників відсутня єдина позиція щодо можливості, умов та порядку припинення деліктних зобов'язань переданням відступного. Автором із цього приводу обгрунтовується думка, що необхідним $€$ забезпечення належного рівня законодавчого регулювання випадків застосування відступного в позадоговірних зобов'язаннях з тим, щоб запобігти зловживанню відступним з метою ухилення від відповідальності за заподіяну шкоду та порушенню права потерпілого на повне відшкодування завданої шкоди.

Крім того, зроблено висновок, що застосування інституту відступного з метою припинення деліктного зобов'язання має здійснюватися з деякими застереженнями, зокрема, на думку автора, порядок та умови його застосування мають відповідати вимозі задоволення інтересів потерпілої сторони у відшкодуванні шкоди в повному обсязі. Хоча це і є певним обмеженням сторін у вільному визначенні розміру відступного, проте цілком відповідає природі позадоговірного зобов'язання.

Звертається увага, що застосування інституту відступного, зокрема в грошових зобов'язаннях, $€$ ефективним механізмом припинення небажаних правових зв'язків між сторонами основного зобов'язання, що дозволяє досягнути вигідних для обох сторін умов на конкретному етапі розвитку правовідносин. Проте важливим є виконання необхідних вимог щодо фіксації всіх істотних умов угоди про передачу відступного.

Проведене дослідження відкриває нові напрями для подальших наукових пошуків, демонструє актуальність і необхідність більш детального та комплексного аналізу досліджуваної проблематики, в тому числі вивчення зарубіжного досвіду в питаннях правового регулювання припинення окремих видів зобов'язань відступним.
Ключові слова: відступне, деліктне зобов'язання, припинення цивільного зобов'язання, угода про передання відступного.

\section{Summary}

Rasskazova $V$. V. Termination of certain types of obligations by retreat. - Article.

Based on the available scientific developments and case law, the article examines the features and general possibility of using a retreat as one of the most flexible and universal tools for terminating contractual and non-contractual obligations, taking into account their legal nature.

According to the results of the research there is no consensus among scientists on the possibility, conditions and procedure for termination of tort obligations by transferring the retreat. In this regard, the author substantiates the opinion that it is necessary to ensure an appropriate level of legal regulation of cases of application of the retreat in non-contractual obligations in order to prevent abuse of the indemnity in order to avoid liability for damages and violation of the victim's right to full compensation.

In addition, it was concluded that the application of the institution of retreat in order to terminate the tort obligations should be subject to certain reservations, in particular, in the opinion of the author, the procedure and conditions of its application should meet the requirements of the interests of the injured party in compensation.

Although this is a restriction on the parties' freedom to determine the amount of the retreat,it is in line with the nature of the non-contractual obligation.

It is noted that the application of the institution of retreat, in particular in monetary obligations, is an effective mechanism for terminating undesirable legal ties between the parties to the main obligation, which allows to achieve favorable conditions for both parties at a particular stage of legal relations. However, it is important to execute the necessary requirements to fix all the essential terms of the transfer agreement.

The research opens new directions for further analysis, demonstrates the relevance and necessity of a more detailed and comprehensive research of the issues under this article, including the exploration of foreign experience in the legal regulation of the termination of certain types of obligations.

Key words: retreat, tortious obligation, termination of civil obligation, agreement on transfer of retreat. 